\title{
The Effects Of Financial Drivers On Corporate Diversification: A Comparison Of Listed And Unlisted Italian Firms
}

\author{
Raffaele Staglianò, Groupe Sup de Co Montpellier Business School, France \\ Maurizio La Rocca, University of Calabria, Italy \\ Alfio Cariola, University of Calabria, Italy
}

\begin{abstract}
The purpose of this paper is to investigate the relationships between related and unrelated corporate diversification and financial drivers by comparing listed and unlisted Italian firms. The agency costs of free cash flow and the internal capital market perspective help to explain these relationships. This research study adopts a quantitative approach and uses a unique panel of hand-collected data on Italian firms for the period from 1980 to 2006. The results of the applied model used in this paper reveal the benefits which arise from an efficient internal capital market. These benefits are especially relevant for unrelated diversification decision-making and for unlisted firms. The findings of this paper are confirmed by an analysis of the performances of the sample firms.
\end{abstract}

Keywords: Corporate Diversification; Listed and Unlisted Italian Firms; Financial Drivers

\section{INTRODUCTION}

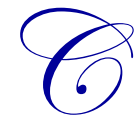

orporate diversification has been a subject of considerable interest in strategic and financial studies, and there is substantial empirical work confirming the existence of a relationship between corporate diversification and firm value. However, there is no consensus about the causal direction of this relationship (Martin and Sayrak, 2003; Bausch and Pils, 2009).

Financial studies offer two fundamental viewpoints on the theoretical motivations for diversification: the agency costs of free cash flow and the internal capital market. The first viewpoint considers diversification to be a decision made for opportunistic reasons, such as power and prestige, empire building and entrenchment (Jensen, 1986; Aggarwal and Samwick 2003). The second view identifies the benefits of an internal capital market for providing financial viability to firm investments, for avoiding transaction costs, including the costs of information asymmetry associated with external finance and, more generally, for avoiding problems arising from financial constraints (Stein, 1997; Doukas and Kan, 2008).

Our study contributes to the literature in at least two ways. First, most of the research on corporate diversification has been performed using US data (Lang and Stulz, 1994; Berger and Ofek, 1995; Aggarwal and Samwick 2003; Doukas and Kan, 2008). This article differs from prior research because it compares the agency costs of free cash flow arguments with internal capital market perspectives in the context of the Italian business environment, an especially suitable analytical context. As Bianco and Casavola (1999) and Faccio and Lang (2002) argue, Italy represents an interesting case for examining which of the two competing theories prevails. This country's institutional context involves significant asymmetric information issues, inefficiencies in existing external capital markets (which produce a need for internal capital markets) and opportunism problems with respect to the use of free cash flow by firm managers and large controlling shareholders (which damages the interests of minority shareholders and other stakeholders). 
Second, we compare listed and unlisted Italian firms to provide new insights on corporate diversification decisions. The literature seems to provide limited information relating to this comparison (Zingales, 2000). Recent studies have suggested that the impact of agency and information asymmetries explanations for corporate decisionmaking differs for a firm depending on whether the firm is listed or unlisted (e.g., Loderer, and Waelchli, 2010).

The paper is organized as follows. First, by providing a theoretical background for our study, we establish the theoretical relationships between diversification and the performance of a firm with consideration of whether a firm is listed or unlisted. We then introduce our research methods, and report the results of our analyses. Finally, we close with concluding remarks.

\section{RELATED LITERATURE}

Our study connects disparate literature that examines the relation between corporate diversification and performance and the differing diversification strategies used by listed and unlisted firms. In this section, we review prior literature in these areas and describe how our study contributes to each area.

\section{The Determinants of Corporate Diversification and Performance}

While the diversification issue can be examined from several different perspectives, ${ }^{1}$ recent well-developed literature in finance investigates the issue from a valuation perspective. A relevant subset of literature suggests that corporate diversification is motivated by a search for private benefits (e.g., Jensen and Meckling, 1976; Jensen, 1986). In particular, diversification may arise as a result of a failure in a corporate governance system. In such instances, managers who diversify inappropriately should be penalized. From this point of view, diversification may destroy investor value.

From a theoretical point of view with an opposite perspective, Gertner et al. (1994) and Stein (1997) analyze the benefits of an internal capital market in providing for the financial viability for firm investments. According to the internal capital markets hypothesis, corporate diversification is expected to result in efficiency gains arising from the development of internal capital markets in diversified firms.

The goals of diversification decision-making and the context of analysis shape the roles of these two counteracting effects. In general, diversification antecedents are mostly considered solely in terms of a firm's decision to diversify into more than one business. However, different underlying motivations for diversifying into new industries exist, at least theoretically, because the new activities pursued by a diversifying firm may be related or unrelated to the firm's core-business. Thus, sorting diversification phenomena into related and unrelated diversification may illustrate the reasons behind a firm's decision to diversify (Palich et al., 2000; Ramaswamy et al., 2004). According to prominent literature, the effect of diversification on performance is expected to be particularly notable when considering a firm that diversifies into business segments dissimilar to the firm's core business because of the different industry aspects of the unrelated industries (e.g., Palich et al., 2000).

Dundas and Richardson (1980) and Khanna and Palepu (1997, 2000) argue that the direction of diversification is based on specific types of market failure. Imperfections in a product and in technological markets lead to related diversified firms, while financial capital market failure and inefficiency in the financial system lead to unrelated diversified firms. Therefore, taking into account related and unrelated diversification and the institutional environments in which firms are based, different motivations for diversification may underpin management decision-making (Fauver et al., 2003).

This study provides a preliminary analysis of the financial drivers of corporate diversification decision and next examines the impact of corporate diversification on performance. Theoretical studies (Lewellen, 1971; Jensen, 1986; Stein, 1997) and empirical evidences (Hyland and Diltz 2002; Doukas and Kan 2008) have suggested that cash flow and debt can be important proxies of the effects of the previously mentioned arguments by affecting diversification decision-making. Cash Flow and Debt are two financial variables that can differently support the

\footnotetext{
${ }^{1}$ Management, financial and economic literature explaining why firms diversify is synthesized by Montgomery (1994).

1460 Copyright by author(s) $\underline{\text { Creative Commons License CC-BY }} 2013$ The Clute Institute
} 
agency costs of free cash flow arguments and the internal capital market perspective. According to the agency costs of free cash flow arguments, we would expect a positive coefficient for variable Cash Flow as results of management's personal discretion and a positive coefficient for the variable Debt if debt can serve as a monitoring devise (e.g., Jensen, 1986; Hyland and Diltz, 2002). Conversely, according to the internal capital market perspective, we would expect the variable Cash Flow (Debt) negatively (positively) impact on corporate diversification decisions. Firms with high cash flow, enjoy easier access to credit which have less interest in the benefits of internal capital markets. Consistent with this alternative perspective if firm's debt increases, the firm may be interested in diversifying its business to acquire greater debt servicing capacity (e.g. Stein, 1997; Doukas and Kan 2008). Moreover, according to prominent literature (Palich et al., 2000) the effect of cash flow and debt on diversification is expected to be particularly relevant for unrelated diversified firms.

\section{Corporate Diversification for Listed and Unlisted Firms}

A firm's listing status certainly has important consequences on the relationships that are being examined. Unlisted firms suffer from a lack of potential relevant funding sources from the stock market (Pagano et al., 1998; Kim, 1999; Kim and Weisbach, 2005). The benefits associated with internal capital market creation could therefore be higher for unlisted firms. Operating outside of the regulation and transparency controls of the stock market, unlisted firms are considerably more opaque than listed firms. The investment expenditures of unlisted firms are more strongly dependent on internal resources compared to listed firms. This dependency results from higher information costs in external capital markets and from the lack of public valuation as a mechanism for aggregating investor information. Consequently, unlisted firms, which are particularly subject to asymmetric information and financial constraints, may be interested in corporate diversification, especially in unrelated diversification, because diversification allows these firms to gain financial stability by reaping the benefits provided by internal capital markets. A binary variable (D_Unlisted, equal to one for unlisted firms and zero otherwise) is used for testing our model.

Listed firms face both agency problems arising from the existence of controlling and non-controlling shareholders and from the separation of ownership from management (Loderer and Waelchli, 2010). These problems are likely to be exacerbated in the presence of a regulatory environment with weak disclosure requirements, poor governance mechanisms and poorly developed financial markets, such as the regulatory environment in Italy (La Porta et al., 2008).

\section{DATA AND METHODOLOGY}

Mediobanca Ricerche \& Studi $(\mathrm{R} \& S)$ provide the data for our study. The data provided are from a unique hand-collected database. Following the approach of prior literature on firm diversification (e.g., Lang and Stulz, 1994; Berger and Ofek, 1995), financial companies are excluded. To reduce the impact of outliers, all explanatory variables are trimmed at the $1 \%$ and at the $99 \%$ tails. The sample consists of 1,934 non-financial firm-year observations for 163 listed and unlisted Italian firms evaluated in the period from 1980 to 2006 (27 years). Italy is characterized by market inefficiency resulting from relevant asymmetric information, and from considerable and perhaps overly broad discretionary power by managers or controlling shareholders of Italian firms to use financial resources, potentially even for opportunistic behavior ${ }^{2}$. Our sample also includes unlisted global players such as Ferrero, Galbani and Ermenegildo Zegna.

The model used to test what are the financial drivers of corporate diversification decision is as follows:

Diversification $_{i t}=\mathrm{b}_{0}+\mathrm{b}_{1}$ Cash Flow $_{i t-l}+\mathrm{b}_{2}$ Debt $_{i t-l}+\mathrm{b}_{\mathrm{n}}$ Control Variables $_{i t-1}$

The diversification activity of firm $i$ at time $t$ is a function of the variable Cash Flow, Debt and a set of control variables at time $t-1$.

\footnotetext{
${ }^{2}$ Capital markets in Italy are relatively undeveloped, with a small number of listed firms and corporate debt mainly raised from banks. Control is concentrated in families at the top levels of management, as a by-product of the relative lack of protection of minority shareholders by Italian securities law.
} 
As Campa and Kedia (2002) suggest, a dummy variable (D_Diversification) is used with a value of one when the firm operates in more than one segment (diversified firm) and with a value of zero otherwise (focused firm). The decision to diversify into related business is measured by using a dummy related to diversification with a (D_Related) value of one if the firm reports business segment differences based on three or four-digit industry codes in conjunction with a two-digit industry code and with a value of zero otherwise. The decision to diversify into an unrelated business is measured by using a dummy (D_Unrelated) with a value of one if at least one business division is different than the firm's existing two-digit industry codes and with a value of zero otherwise. ${ }^{3}$ Because the values of the dependent variables are binary, probit regression models are used.

Variable Cash Flow is defined as the ratio of EBITDA as scaled by total assets. Variable Debt is measured as the ratio of financial debt as scaled by total assets.

Additional control variables are included in the model, such as D_Listing (a binary variable with a value of one if a firm is listed and with a value of zero otherwise), D_Family (a binary variable with a value of one if a member of a e firm's founding family participates in ownership and with a value of zero otherwise), Owner Conc (the percentage of shares that are held by the largest shareholder of a firm), Growth opp (the annual percentage change in sales for a firm), Size (the natural logarithm of the total assets of a firm) and Tangibility (the value of property, plant and equipment as a share of a firm's total assets). Explanatory variables are lagged by one period. Year dummies and industry dummies are also used.

Because of the different motivations underlying the decision to diversify into related or unrelated activities, we intend to verify the impact of diversification decision-making on a firm's performance. We applied return on assets (ROA) as the measure of corporate performance, which is calculated as operating profit divided by total assets. We used dummies variables to classify diversification (D_Diversification, D_Related, and D_Unrelated) with the goal of determining the existence of a positive or negative relation between diversification and performance. Moreover, to verify the effect of diversification on the performances of listed and unlisted sample firms, we ran regressions separately for the listed and unlisted samples.

From an econometric perspective, we chose to run a system GMM (SYSGMM) estimator as proposed by Arellano and Bover (1995) and Blundell and Bond (1998), to explicitly deal with unobservable heterogeneity and to control for the endogeneity problem.

\section{RESULTS}

Table 1 presents the means, the median and standard deviations of the variables used in our empirical analysis. The table also compares the mean values for focused and diversified firms, reporting the p-values for t-tests on the differences in means.

Table 1. Descriptive Statistics

\begin{tabular}{lcccccc}
\hline \multicolumn{1}{c}{ Variables } & Mean & $\begin{array}{c}\text { Whole Sample } \\
\text { Median }\end{array}$ & St.Dev. & $\begin{array}{c}\text { Focused firms } \\
\text { Mean }\end{array}$ & $\begin{array}{c}\text { Diversified firms } \\
\text { Mean }\end{array}$ & $\begin{array}{c}\text { Foc. vs Div. } \\
\text { (p-value) }\end{array}$ \\
\hline D_Diversif. & 0.54 & 1 & 0.49 & & & \\
D_Related & 0.33 & 0 & 0.47 & & & \\
D_Unrelated & 0.34 & 0 & 0.47 & 0.17 & 0.13 & 0.01 \\
Cash Flow & 0.13 & 0.12 & 0.15 & 0.42 & 0.45 & 0.00 \\
Debt & 0.44 & 0.44 & 0.23 & 0.25 & 0.62 & 0.00 \\
D_Listing & 0.33 & 0 & 0.47 & 0.58 & 0.64 & 0.00 \\
D_Family & 0.61 & 1 & 0.48 & 0.68 & 0.09 & 0.00 \\
Owner.Conc. & 0.66 & 0.64 & 0.25 & 0.12 & 0.03 & 0.11 \\
Growth opp. & 0.10 & 0.06 & 0.33 & 0.03 & 0.34 & 0.00 \\
Size & 20.05 & 20.10 & 1.31 & 0.33 & & 0.01 \\
Tangibility & 0.34 & 0.32 & 0.15 & & & \\
\hline
\end{tabular}

\footnotetext{
${ }^{3}$ We used Italian classification codes (ATECO).
} 
Considering the descriptive statistics for the whole sample, we found that 54 percent of the firms are diversified. Some variables, such as debt, seem to be symmetrically distributed among the sample firms, while other variables, such as growth opportunity, are asymmetrically distributed. The results of mean comparison t-tests indicate that diversified firms appear to have significantly different features compared to their specialized counterparts.

Table 2 presents results based on the general model that we used (1). We run three different models to verify the determinants of total diversification (column 1), related diversification (column 2) and unrelated diversification (column 3).

Table 2. The Results of the General Model

\begin{tabular}{lccc}
\hline \multicolumn{1}{c}{ Variables } & $\begin{array}{c}\text { D_Diversification } \\
(\mathbf{1})\end{array}$ & $\begin{array}{c}\text { D_Related } \\
(\mathbf{2})\end{array}$ & $\begin{array}{c}\text { D_Unrelated } \\
(\mathbf{3})\end{array}$ \\
\hline Cash Flow & $-0.574(0.26)^{* *}$ & $-0.165(0.13)$ & $-0.324(0.19)^{*}$ \\
Debt & $0.497(0.17)^{* * *}$ & $0.108(0.08)$ & $0.270(0.09)^{* * *}$ \\
D_Listing & $0.335(0.08)^{* * *}$ & $0.155(0.09)^{*}$ & $0.162(0.0 .08)^{* *}$ \\
D_Family & $-0.133(0.17)$ & $0.058(0.05)$ & $-0.221(0.13)$ \\
Owner.Conc. & $-0.103(0.14)$ & $-0.13(0.06)^{*}$ & $0.074(0.04)$ \\
Growth Opp. & $-0.112(0.10)$ & $0.022(0.04)$ & $-0.071(0.06)$ \\
Size & $0.087(0.03)^{* *}$ & $-0.024(0.02)$ & $0.107(0.04)^{* * *}$ \\
Tangibility & $-0.976(0.32)^{* * *}$ & $-0.31(0.14)^{* *}$ & $-0.425(0.20)^{* *}$ \\
\hline Num. obs. & 1934 & 1934 & 1934 \\
Log Likelihood & -1292.3 & -1129.0 & -1208.2 \\
Wald test (df) & $62.4(33)^{* * *}$ & $81.5(33)^{* * *}$ & $57.2(34)^{* * *}$ \\
\hline Notes: $(*),(* *)$ and $(* * *)$ & & \\
\hline
\end{tabular}

Notes: $(*),(* *)$ and $(* * *)$ indicate that coefficients are significant at the 10,5 and 1 percent levels, respectively. Clustered robust standard errors are denoted in parentheses. Industry dummies and time period dummies are included in the regressions, although this table does not report these results.

The variable Cash Flow in regressions (1) is negatively associated with the decision to generally diversify. This negative result seems to be driven by unrelated diversification. Indeed, Cash Flow in regressions (3) is also negative. The results of the variable Cash Flow suggest that firms that are able to generate higher cash flow are also less financially constrained, resulting in such firms beings less interested in diversification. For these firms, because they face easier access to credit and cheaper costs of capital resulting from a higher availability of financing, the benefits provided by financial synergies are not a key competing factor.

The positive effect of the variable Debt for general diversification decision-making (column 1) and for unrelated diversification decision-making (column 3), implies that debt pushes managers to diversify to reduce operating risks, supporting a coinsurance effect, rather than acting as a disciplining device against managerial opportunistic behavior. In summary, the results in Table 2 provide support for the importance of the internal capital market perspective, particularly highlighting the relevance of financial synergy motivations in decisions relating to unrelated diversification.

Because we find listed status to be a driver for diversification decision-making, in table 3 , we provide a deeper analysis of the determinants of diversification using an interaction term that shows different coefficients for listed firms as opposed to unlisted firms. We use a dummy D_UnListing with a value of one if a firm is unlisted. 
Table 3. Unlisted Firms versus Listed Firms

\begin{tabular}{lccc}
\hline \multicolumn{1}{c}{ Variables } & $\begin{array}{c}\text { D_Diversification } \\
(\mathbf{1})\end{array}$ & $\begin{array}{c}\text { D_Related } \\
(\mathbf{2})\end{array}$ & $\begin{array}{c}\text { D_Unrelated } \\
\mathbf{( 3 )}\end{array}$ \\
\hline Cash flow & $0.139(0.38)$ & $0.32(0.17)^{* *}$ & $-0.136(0.07)^{*}$ \\
Cash flow x D_UnListing & $-0.220(0.16)^{*}$ & $0.211(0.20)$ & $-0.46(0.21)^{* *}$ \\
Debt & $-0.438(0.21)^{*}$ & $-0.29(0.16)^{*}$ & $0.054(0.04)^{*}$ \\
Debt x D_UnListing & $0.196(0.08)^{* *}$ & $0.128(0.34)$ & $0.380(0.14)^{* * *}$ \\
Control variables & $Y E S$ & $Y E S$ & $Y E S$ \\
\hline Num. Obs. & 1934 & 1934 & 1934 \\
Log Likelihood & -1282.3 & -1125.5 & -1186.9 \\
Wald test (df) & $71.8(35)^{* * *}$ & $84.9(35)^{* * *}$ & $77.8(35)^{* * *}$ \\
\hline
\end{tabular}

Notes: $\left(^{*}\right),(* *)$ and $(* * *)$ indicate that coefficients are significant at the 10,5 and 1 percent levels, respectively. Clustered robust standard errors are denoted in parentheses. In all of the regressions, the same previously mentioned set of control variables is used. Other explanatory variables, industry dummies and time period dummies are included in the regressions, although this table does not report these results.

Unlisted firms should be particularly interested in the benefits provided by internal capital markets. Table 3 (column 1) shows that for unlisted firms variable Cash Flow is negatively related to general diversification and that variable Debt is positively related to general diversification. We interpret these results with consideration of the fact that unlisted firm investments depend more strongly upon internal resources than listed firm investments. According to Kim and Weisbach (2005), Kim (1999) and Pagano et al. (1998) unlisted firms, particularly those firms affected by asymmetric information and financial constraints, show interest in diversification, especially in unrelated diversification, for the purpose of building financial stability.

For listed firms, the signs of the coefficients of variables Cash Flow and Debt are consistent with agency costs arguments. According to Loderer and Waelchli (2010), our results confirm that listed firms, compared with unlisted firms, face problems of opportunistic behaviors by managers and controlling shareholders. Our results may arise as a consequence of the features of the Italian financial environment in which financial markets are poorly developed and disclosure requirements and governance mechanisms are weak.

Our results also show different managerial motivations for diversification depending on whether the diversification is into related areas or unrelated areas. For unlisted firms, the results strongly show the relevance of financial motivations in affecting unrelated diversification decisions. However, considering listed firms, we find support that opportunistic motivations affect related diversification decisions. Extending the general results, we determine that the choices of unlisted firms to pursue unrelated diversification accords with the internal capital market perspective.

The analysis also applies different measures for variables Cash Flow and Debt to measure robustness; however, the findings (not reported) are invariant. Furthermore, to check the robustness of the findings, as Hoetker (2007) and Williams (2009) suggest, models (1) to (3) of Table 3 are re-estimated using a heteroskedastic probit model, to detect and to adjust for differences in residual variations and for false differences in coefficients between groups (listed and unlisted firms). The empirical findings of this test for the relation between diversification and interaction terms (not reported) show similar results to the main model.

Finally, we examine the impact of diversification on performance. The connection between diversification and performance depends on the motivations associated with this corporate strategy. If diversification is motivated by the benefits provided by an internal capital market, a positive effect on performance is expected especially for unlisted firms. Conversely, if diversification is motivated by opportunistic motivations, a negative effect on performance is expected especially for listed firms. 
Table 4. Diversification and Firm Performance for Listed and Unlisted Firms ${ }^{4}$

\begin{tabular}{|c|c|c|c|c|}
\hline \multirow{3}{*}{ Variables } & \multicolumn{4}{|c|}{ Sys-Gmm Regressions } \\
\hline & ROA & ROA & ROA & ROA \\
\hline & Listed Firm & Listed Firm & Unlisted Firm & Unlisted Firm \\
\hline D_Diversification & $\begin{array}{c}0.099 \\
(0.141)\end{array}$ & $\begin{array}{c}-0.331 * * \\
(0.161)\end{array}$ & $\begin{array}{l}-0.084 \\
(0.092)\end{array}$ & $\begin{array}{c}-0.367 * * * \\
(0.117)\end{array}$ \\
\hline D_Related & $\begin{array}{c}-0.232 * * \\
(0.107)\end{array}$ & & $\begin{array}{c}-0.175^{* *} * \\
(0.081)\end{array}$ & \\
\hline D_Unrelated & & $\begin{array}{c}0.375 * * * \\
(0.139)\end{array}$ & & $\begin{array}{c}0.384 * * * \\
(0.065)\end{array}$ \\
\hline Control variables & YES & YES & YES & YES \\
\hline Num. Obs. & 1633 & 1633 & 1633 & 1633 \\
\hline Model-test & 134.90 .000 & 134.90 .000 & 86.800 .000 & 86.800 .000 \\
\hline AR1 test & -3.900 .000 & -3.900 .000 & -3.290 .001 & -3.290 .001 \\
\hline AR2 test & -0.050 .964 & -0.050 .964 & -0.370 .709 & -0.370 .709 \\
\hline Hansen test & 65.310 .363 & 65.310 .363 & 89.090 .331 & 89.090 .331 \\
\hline
\end{tabular}

Notes: $(*),(* *)$ and $(* * *)$ indicate that coefficients are significant at the 10,5 and 1 percent levels, respectively. In all of the regressions, the same previously mentioned set of control variables is used. Other explanatory variables, industry dummies and time period dummies are included in the regressions, although this table does not report these results.

In general, the results in Table 4 suggest that unrelated diversification positively affects corporate performance, while diversification into related businesses has a negative impact on performance.

Our results underline the positive effect of unrelated diversification on performance. These results support the role of the internal capital market arguments for diversification. Similar to the results of Fauver et al. (2003) and Khanna and Palepu (1997), our sample achieves the benefits provided by diversification strategies, arising from internal capital markets. The positive effect of internal capital markets appears stronger in the presence of significant external capital market constraints and imperfections, which are constraints frequently faced by unlisted Italians firms.

The reported negative effect of related diversification on firm performance supports the agency costs of free cash flow arguments. As suggested by Markides and Williamson (1996), related diversification has to provide resource sharing and skills transferring based on rare, not-imitable, valuable and not-substitutable resources to be value-enhancing. The lack of one of these properties can generate inefficiency and additional costs. This result can also be interpreted according to Nayyar (1992), who suggested that relatedness can fail to create value when the involved business units fail to cooperate with each other or when incentives generate impediments to relatedness exploitation. Consistent with previous results, we find higher coefficients for listed firms. Therefore, the decisions of Italian firms to pursue related diversification are mainly motivated by opportunistic behaviors rather than by desires for creating operational synergies.

\section{CONCLUSION}

This paper investigates the role of financial drivers as diversification antecedents by evaluating the agency costs of free cash flow arguments and the internal capital market perspectives. The results reveal, overall, the predominance of internal capital market arguments over agency costs of free cash flow arguments. In other words, the benefits of diversification (avoiding costly external finance) outweigh the costs of diversification (arising from problems of opportunistic decision-making). In an institutional context such as Italy, full of frictions and inefficiencies, firms mainly diversify for financial purposes: to benefit from the creation of internal capital markets, to be better able to handle interest payments on debt and to reduce financial risk. The benefits associated with internal capital markets are especially relevant for unrelated diversification decision-making.

\footnotetext{
${ }^{4}$ For the SYS-GMM regressions, the key assumptions are verified. The autocorrelation tests signal a strong first order correlation in the differenced residuals, but no higher order autocorrelation, therefore, supporting the assumption of a lack of autocorrelation in the errors of levels, underlying the adopted estimator. Further, the Hansen test cannot reject the null hypothesis of the validity of the over identifying restrictions. The difference in Hansen test supports the validity of the additional instruments used by the SYS-GMM estimator. Therefore, the features of our model were valid and well-specified.
} 
This paper enriches the literature on corporate diversification by exploring the impact of financial drivers on corporate diversification in listed and unlisted firms. Our results suggest the possible role of the agency costs of free cash flow arguments in explaining listed firm decision-making regarding related diversification. In contrast, for unlisted firms, the internal capital market perspective appears to be more effective in explaining decisions to undergo unrelated diversification.

Finally, this paper provides direct evidence of the impact of diversification on performance. Empirically, taking into account endogeneity problems in diversification decision-making, we find that related diversification strategies have a negative impact on performance especially for listed firms. This result is consistent with the agency costs of free cash flow arguments. Unrelated diversification strategies, especially for unlisted firms, create a positive effect on performance consistent with the efficient view of corporate diversification.

As highlighted by the results, because of the relevance of the benefits of internal capital markets for unlisted Italian firms, this study offers insights into the existence of noteworthy inefficiencies in the Italian external capital market. Policy-makers should be involved in designing policies that improve corporate laws and promote institutional activities that protect investors. Moreover, given the resulting importance of the typical conflicts of interest arising between majority shareholders and minority investors, which affects Italian listed firms, policymakers should improve the governance systems that protect outsiders. In fact, the one-dimensional features of the Italian stock market and the low growth rate of the Italian stock market may be directly affected by the extent of these agency problems.

\section{AUTHOR INFORMATION}

Raffaele Stagliano, Ph.D., is an Assistant Professor of Finance at Groupe Sup de Co Montpellier Business School (France). His research focuses on corporate finance and corporate governance. Department of Law Accounting and Finance, Groupe Sup de Co Montpellier Business School, Montpellier Research in Management, 2300 Avenue des Moulins, 34185 Montpellier, France. E-mail: r.stagliano@supco-montpellier.fr

Maurizio La Rocca, Ph.D., is Associate Professor in Business Economics and Management at the University of Calabria (Campus of Arcavacata - Cosenza, Italy). His research interests concerns topics related to capital structure, corporate diversification, corporate governance and value creation. University of Calabria, Department of Business Administration and Law, Cubo 3C, Campus of Arcavacata, 87036 Rende, Cosenza, Italy. Email: m.larocca@unical.it (Corresponding author)

Alfio Cariola, Ph.D., is Full Professor in Business Economics and Management at the University of Calabria (Campus of Arcavacata - Cosenza, Italy). His research interests concerns topics related to capital structure and value creation. University of Calabria, Department of Business Administration and Law, Cubo 3C, Campus of Arcavacata, 87036 Rende, Cosenza, Italy. E-mail: a.cariola@unical.it

\section{REFERENCES}

1. Aggarwal, R.K., \& Samwick, A.A. (2003). Why do managers diversify their firms? Agency reconsidered. The Journal of Finance, 58(1), 71-118.

2. Arellano, M., \& Bover, O. (1995). Another look at the instrumental variable estimation of errorcomponents models. Journal of Econometrics, 68(1), 29-51.

3. Bausch, A., \& Pils, F. (2009). Product diversification strategy and financial performance: meta-analytic evidence on causality and construct multidimensionality. Review of Managerial Science, 3(3), 157-190.

4. Berger, P. G., \& Ofek, E. (1995). Diversification's effect on firm value. Journal of Financial Economics, 37(1), 39-65.

5. Bianco, M., \& Casavola, P. (1999). Italian corporate governance: Effects on financial structure and firm performance. European Economic Review, 43(4), 1057-1069.

6. Blundell, R., \& Bond, S. (1998). Initial conditions and moment restrictions in dynamic panel data models. Journal of Econometrics, 87(1), 115-143. 
7. Campa, J. M., \& Kedia, S. (2002). Explaining the diversification discount. The Journal of Finance, 57(4), 1731-1762.

8. Doukas, J. A., \& Kan, O. B. (2008). Investment decisions and internal capital markets: Evidence from acquisitions. Journal of Banking \& Finance, 32(8), 1484-1498.

9. Dundas, K. N., \& Richardson, P. R. (1980). Corporate strategy and the concept of market failure. Strategic Management Journal, 1(2), 177-188.

10. Faccio, M., \& Lang, L. H. (2002). The ultimate ownership of Western European corporations. Journal of Financial Economics, 65(3), 365-395.

11. Fauver, L., Houston, J., \& Naranjo, A. (2003). Capital market development, international integration, legal systems, and the value of corporate diversification: A cross-country analysis. Journal of Financial and Quantitative Analysis, 38(1), 135-158.

12. Gertner, R. H., Scharfstein, D. S., \& Stein, J. C. (1994). Internal versus external capital markets. The Quarterly Journal of Economics, 109(4), 1211-1230.

13. Hoetker, G. (2007). The use of logit and probit models in strategic management research: Critical issues. Strategic Management Journal, 28(4), 331-343.

14. Hyland, D. C., \& Diltz, J. D. (2002). Why firms diversify: An empirical examination. Financial Management, 51-81.

15. Jensen, M. (1986). Agency cost of free cash flow, corporate finance, and takeovers. Corporate Finance, and Takeovers. American Economic Review, 76(2).

16. Jensen, M. C., \& Meckling, W. H. (1976). Theory of the firm: Managerial behavior, agency costs and ownership structure. Journal of Financial Economics, 3(4), 305-360.

17. Khanna, T., \& Palepu, K. (1997). Why focused strategies may be wrong for emerging markets. Harvard Business Review, 75(4), 41-48.

18. Khanna, T., \& Palepu, K. (2000). Is group affiliation profitable in emerging markets? An analysis of diversified Indian business groups. The Journal of Finance, 55(2), 867-891.

19. Kim, J. (1999). The relaxation of financing constraints by the initial public offering of small manufacturing firms. Small Business Economics, 12(3), 191-202.

20. Kim, W., \& Weisbach, M. (2005). Do firms go public to raise capital? (No. w11197). National Bureau of Economic Research.

21. Lang, L. H., \& Stulz, R. M. (1994). Tobin's q, corporate diversification, and firm performance. Journal of Political Economy, 1248-1280.

22. La Porta, R., Lopez de Silanes, F. \& Shleifer, A. (2008). The Economic Consequences of Legal Origins. Journal of Economic Literature, 46(2), 285-332.

23. Lewellen, W. G. (1971). A pure financial rationale for the conglomerate merger. The Journal of Finance, 26(2), 521-537.

24. Loderer, C., \& Waelchli, U. (2010). Protecting minority shareholders: Listed versus unlisted firms. Financial Management, 39(1), 33-57.

25. Markides, C. C., \& Williamson, P. J. (1996). Corporate diversification and organizational structure: a resource based view. Academy of Management Journal, 39(2), 340-367.

26. Martin, J. D., \& Sayrak, A. (2003). Corporate diversification and shareholder value: a survey of recent literature. Journal of Corporate Finance, 9(1), 37-57.

27. Montgomery, C. A. (1994). Corporate diversification. The Journal of Economic Perspectives, 8(3), $163-$ 178.

28. Nayyar, P. R. (1992). On the measurement of corporate diversification strategy: Evidence from large US service firms. Strategic Management Journal, 13(3), 219-235.

29. Pagano, M., Panetta, F. \& Zingales, L. (1998). Why do companies go public? An empirical analysis. The Journal of Finance, 53(1), 27-64.

30. Palich, L., Cardinal, L. \& Miller, C. (2000), Curvilinearity in the diversification-performance linkage: An examination of over three decades of research. Strategic Management Journal, 21(2), 155-174.

31. Ramaswamy, K., Li, M., \& Petitt, B. S. P. (2004). Who drives unrelated diversification? A study of Indian manufacturing firms. Asia Pacific Journal of Management, 21(4), 403-423.

32. Stein, J. C. (1997). Internal capital markets and the competition for corporate resources. The Journal of Finance, 52(1), 111-133. 
33. Williams, R. (2009). Using heterogeneous choice models to compare logit and probit coefficients across groups. Sociological Methods \& Research, 37(4), 531-559.

34. Zingales, L. (2000). In search of new foundations. The journal of Finance, 55(4), 1623-1653. 